\title{
Postmodernism, Knowledge Building, and Elementary Science
}

\author{
Carl Bereiter \\ Marlene Scardamalia \\ Ontario Institute for Studies in Education of the \\ University of Toronto \\ Carol Cassells \\ Taft Middle School \\ Cedar Rapids, lowa \\ James Hewitt \\ Ontario Institute for Studies in Education of the \\ University of Toronto
}

\begin{abstract}
Postmodernist challenges to the status of science and scientific knowledge have intensified concerns about how these topics should be treated in schools. Science, we argue, need not be presented either as a grand march toward Truth or as a body of dubious opinions and practices. Instead, it may be presented as a continuing effort to improve on existing knowledge-an effort students can participate in. Instead of an enthroned "scientific method," there is a commitment to discourse that advances mutual understanding. A 3-monthlong discourse carried out by sixth graders is analyzed to show that the basic commitments that enable scientific progress can be realized in elementary schools. To be at home in a knowledge-based society, people need to be able to move freely between scientific and other modes of thought, according to the situation and their purposes. The sixth graders' discourse provides a striking illustration of what this can mean.

For almost half a century, educators have been hearing that science is not the body of objective methods and established truths that it had sometimes been made out to be (Kelley, Carlsen, \& Cunningham, 1993). It is probably fair to say that this has been welcome news to most science educators because it has seemed to support the movements toward constructivist, inquiry-oriented approaches that have been gaining favor for other reasons as well. Recently, however, a new wave of criticism has arisen that challenges not only authoritative truth claims but the whole approach to knowing represented by mainstream science-whether carried out in the laboratory or in the classroom (Whitson, 1991). This new wave has brought with it a range of accusations that had not appeared in earlier critiques of science: hegemonic (Kyle, 1991), ethnocentric (Stanfield, 1985), racist (Gill \& Levidow, 1987), and sexist (Bleier, 1988).

The popular term for this new wave of criticism is "postmodernist." The term is appearing everywhere-in art, architecture, theater, philosophy, and
\end{abstract}


social movements-and it does not necessarily have a common meaning across these contexts (Lash, 1990; Smith-Allen, 1992). Although there are philosophers identified with the term--notably, Michel Foucault and Jacques Derrida--the popular movement cannot be said to have close ties to the thinking of these somewhat abstruse writers. Rather, postmodernism as it makes its way into popular culture seems best characterized as an attitude. The postmodernist attitude toward science is the same attitude that is challenging Shakespeare's status in the literature curriculum and Columbus's status in history. It reflects a desire to shift away from a perspective that places the works of "dead white males" at the center and marginalizes everything else. Science is seen as part of this hegemony, and so it needs to be dethroned.

Whereas earlier skeptics maintained a serious respect for science and its accomplishments, postmodernists delight in stripping away its pretensions. For philosophers like Thomas Kuhn, it was obvious that scientific knowledge does progress, and so the problem was how to explain this progress, given the absence of a foundation of objective truth. To postmodernists, there is no progress to be explained: "Modes of social knowledge such as theology, science, and magic are different, not inferior or superior. They represent different ways of perceiving, defining, and organizing knowledge of life experiences" (Stanfield, 1985, p. 392).

In considering the implications of postmodernism for science education, we need to distinguish between two kinds of skepticism. One is skepticism about scientific claims. Such skepticism does not lead to the rejection of science. It is part of being "scientific." Postmodern critics are not interested in questioning particular scientific claims, however. When they put science into the same category as astrology and witchcraft, they are suggesting science as a whole might be supplanted by some other approach to knowledge. And there seems to be a growing sentiment in favor of just that. Such a sentiment has grave implications for education.

The reason this antiscientific sentiment has grave implications for elementary education is that in modern societies there is not actually any alternative to science as a way of satisfying children's natural curiosity about the physical and biological world. We may freely admit that there are other ways of knowing--through art, myth, and religion--and that these address important human needs, but they cannot possibly address the endless flow of why and how questions that will occur in any modern elementary school classroom where they are allowed to flourish. There is no alternative biology that explains what bruises are, how you can resemble your aunt more than you do your mother, why mosquitoes do not transmit AIDS, and why your nose runs when you have a cold. For questions like these, the only real alternative to scientific inquiry is the suppression of inquiry; it is not some alternative form of knowing.

Once it is accepted that science is here to stay, however, large questions remain about how science should be treated in school. For philosophers, the problem of establishing a way of avoiding an unsupportable objectivist stance 
on one hand and a relativistic "everyone is entitled to his or her own opinion" stance on the other is a persisting one. In schooling, the problem is compounded because it pertains not only to what is presented as true or worthy of belief but also to how students are encouraged to think about science and their relation to it. In this article we want to suggest both a novel way of viewing science and a way of teaching that is consistent with it. The way of teaching is one that children take to naturally and that largely circumvents the philosophical dilemma and the more severe of the postmodernist criticisms. Indeed, our observations encourage us to believe that children themselves can work out a reasonable and healthy relationship to science, that adults do not have to work it out for them.

\section{Pursuit of Progress versus Pursuit of Truth}

Sir Karl Popper, one of the earliest and most influential opponents of positivism, acknowledged that one can never know whether one is getting closer to the truth (Popper, 1962, p. 229). The reason is fairly obvious. In order to know that you are getting closer to the truth, you have to know what the truth is, which means that you are already there. Popper argued that, nevertheless, scientists must believe that they are in pursuit of the truth, for otherwise there is no point to what they are doing, no reason to prefer one theory to another. It seems that postmodernists share Popper's assumption but arrive at a different conclusion: because the pursuit of truth is an illusion, there is, indeed, no point to science and no reason to prefer one theory to another.

Both Popper's and the postmodernists views, however, seem to be out of touch with scientific thought as it is lived out by actual, working scientists. From the seminal work of Kunn (1970) to the analyses of theory change by Paul Thagard (1989) and the participant observational research of Kevin Dunbar (1993), a quite different view of scientific progress has emerged. Scientific progress is not a matter of getting closer to the truth; it is a matter of improving on existing knowledge. It is not judged by looking ahead and determining whether the gap between knowledge and ultimate truth is narrowing; virtually everyone now agrees that that is fantasy. Progress is judged by looking backward and comparing today's knowledge with yesterday's. There are various bases of comparison, but generally they involve judging which theory does the best job of accounting for the accepted facts (Harman, 1986). Major scientific advances come about when a new theory not only accounts for existing facts but generates predictions that result in new facts that the new theory accounts for but that older theories do not.

At a general, philosophical level, scientific progress is hard to explain and defend. Postmodernist criticism of science is all aimed at this general level. If you try to stand up for science at this level, you will find yourself in trouble no matter what you say. Either you agree that there is no objective standard for judging progress or you claim that there is. If you claim that there is, you will be battered by the arguments that defeated positivism. If you agree that there is not an objective basis, then you will be admitting that progress is a 
matter of subjective judgment. If you nevertheless persist in upholding a belief in scientific progress, you will be accused of bowing to the prestige of the scientific elite. If you try to be pragmatic and point to space travel and other triumphs of science, you will be taken to task over environmental pollution and destruction of the rain forests.

Rather than trying to defend science at a general level, it is better to focus the discussion on specifics. If someone is making sweeping criticisms of science, ask the person if there is any particular scientific knowledge he or she would quarrel with. In our experience, the only objections critics are likely to make have to do with areas where scientists made unwarranted assumptions or neglected important factors--for instance, in neglecting environmental impact or in studying heart disease in men and assuming the findings applied to women. Such cases, however, provide good examples of the nature of scientific progress. How did we find out about the unwarranted assumptions and neglected factors? Has anything changed? Do we understand these things better now than we did before? Would you not call this progress?

The same basic strategy applies to how scientific progress can be treated in the classroom. There is no reason to portray some general march of science. If a new theory of dinosaur extinction comes along and one wants to present it as an advance, all that is necessary is to show how it is an improvement over preceding theories. Does it explain facts that the others do not? Does it explain the same facts but more simply or convincingly? Not everyone may agree that the new theory is an improvement. Fine. Make it a subject for discussion and further research. Viewing scientific progress as theory improvement has several important implications for education. First, it provides a way to escape from the evils of authoritarianism and absolutism on one side and relativism and subjectivism on the other. Scientific knowledge is never declared to be true or final, but neither is it treated as a matter of subjective opinion. Suppose, as is common, that children theorize that metals expand when heated because their molecules get bigger. Then the students discover, or have it pointed out to them, that according to authoritative sources expansion is due to the molecules moving farther apart. What is the teacher to do about this discrepancy? One approach, which students are likely to adopt spontaneously, is to defer to authority. The book says one thing, we thought another, so we were wrong. Another approach is to treat the two theories as "different, not inferior or superior," to use the previously quoted words of Stanfield (1985). But a more constructive approach would be to treat the discrepancy as an interesting new problem. Both theories explain why metals expand when heated. So let's see if we can find out why scientists prefer the molecules-spreading-apart theory to the molecules-expanding theory. Are there some other things that one theory explains but the other does not? Students will not have to look very far. The molecules-spreading-apart theory also explains changes of state-heated materials getting softer, then becoming liquid, and then turning to a gas--whereas such changes do not fit at all well with molecules getting bigger and bigger as they heat up. The second 
implication of viewing scientific progress as theory improvement is the crucial importance of discourse. There is no objective standard for determining that one theory is an advance over another. It has to be thrashed out case by case, and it can sometimes take years. But there is no way that hands-on empirical investigation alone can do the job. Although such work is important, it has its effect through being brought into the discourse. Thus, there is real substance to the growing interest in "talking science" (Lemke, 1990). The third and most practical implications that the theory-improvement view of science can be applied directly to children's own efforts to understand the world. Presented with a puzzling phenomenon, children will seldom be at a loss for an explanation of some kind. It is likely to be incomplete and to be grounded in intuitive beliefs, but it is a start. By setting about trying to improve their initial theories rather than to attain final answers, children can be practicing science in a way that is consistent with the most modern conceptions of the scientific enterprise.

\section{Scientific Method versus Scientific Commitment}

Is there such a thing as scientific method? Obviously, scientists make use of many specialized techniques and technologies, but these differ from field to field and even from laboratory to laboratory. Is there some more general method, used by scientists in all fields, which produces scientific progress? This has been and remains a contested issue within philosophy of science. According to one view, method distinguishes real science from pseudosciences, such as astrology (e.g., Lakatos, 1970). Scientists have ways of advancing knowledge, of eliminating poor theories and replacing them with better ones, whereas pseudoscientists, mystics, and the like, do not. According to another view, favored by postmodernists, there is nothing that sharply distinguishes the way scientists go about their work from the way other people go about theirs. Such elevated forms of thought as the hypotheticodeductive method are practiced in all walks of life. And scientists reveal all the same foibles as other thinkers. According to this view, all that distinguishes scientists is their "solidarity," as Rorty (1991) put it-their belonging to a community of scientists and adhering to its values and practices.

Both sides agree that, if there is anything distinctive about science, it is not to be found in the workings of individual minds but in the way scientists conduct themselves as a community. The two views are not so far apart, if one considers that the outstanding characteristic of scientific communities is that they are trying to produce scientific progress, to keep replacing existing knowledge with better knowledge. Most human groups and institutions are not engaged in such effort. If they were, they might well succeed, and if they kept at it they would probably come to be regarded as scientific. What it requires is not method but commitment.

If this view of science is tenable, it means that any group could potentially function as a scientific community, and this includes elementary 
school classrooms. Note the shift in focus here from the one traditionally held by advocates of inquiry learning. The focus is not on the individual student and the relation between the student's cognitive processes and those of a research scientist. The focus is on the classroom community and the relation between its commitments and the commitment of a community of scientists to scientific progress. We will explore this relation further in a later section, but first we need to look more deeply into what it means for a community to have a commitment to scientific progress.

\section{Progressive Discourse and Its Commitments}

Although individual scientists and research teams may work with shovels or electromagnetic resonance devices, scientific communities work through discourse--publications, conferences, debates, e-mail messages, bag lunch meetings, and so on. Accordingly, a commitment to scientific progress reveals itself in the sorts of conduct expected of people in scientific discourse. Certain norms apply to discourse of all kinds. Grice (1975) identified these in his well known "conversational postulates." They include trying to be truthful, saying all that is needed to be understood, and saying things relevant to the topic. But four other commitments may be identified, which do not apply to all kinds of discourse but which are important if discourse is to create advances in knowledge. These are adapted from Bereiter (1994):

1. Mutual advances in understanding. This is a commitment to work toward advances in understanding that are satisfactory to all the participants. The ideal is not compromise or grudging assent. The ideal is to achieve something that all persons agree is an improvement over their own previous understanding.

2. Empirical testability. This is a commitment to frame questions and propositions in ways that enable evidence to be brought to bear on them. Of course, people may disagree as to what constitutes relevant evidence, but then that becomes a further matter for discussion, in keeping with the mutual advances in understanding commitment. Honoring the empirical testability commitment means voluntarily making your position vulnerable, which is quite different from the case in debates and in legal briefs, where the objective is to make your position as invulnerable as possible.

3. Expanding the basis for discussion. As Rorty (1991) points out, you cannot disagree with someone unless you already agree with them to a large extent. Otherwise you are in different worlds and can only talk past one another. A commitment to expanding the basis for discussion is a commitment to expand the network of facts and ideas that participants already accept or that they will at any rate not deny (Miller,1987)--thus increasing the possibilities for constructive argument about matters on which participants do not agree.

4. Openness. A weakness in the mutual advances in understanding commitment is that it can most easily be met by avoiding critical thinking. Overcoming this weakness requires a commitment to openness-being open to 
dissent, to challenge, and to new ideas, from outside as well as from inside the group. Although your group may have achieved agreement that Theory $Y$ is a great improvement over Theory $X$, some other group may disagree. You do not tell them to go off and start their own science. You bring them into the discourse and try to achieve a new mutual understanding--Theory $Z$, perhapswhich both groups will recognize as an advance.

Again, we emphasize that these are commitments of a community and that they are not necessarily honored by all members at all times. As an individual, you may be disinclined to pursue mutual understanding with certain people and to make certain of your beliefs vulnerable to negative evidence and criticism. The history of science contains many such instances. But in a well functioning scientific community, dissenting ideas tend eventually to be heard and jealously guarded beliefs to be tested. This is not because of some gravitational pull that draws science ever forward, it is just because in a well functioning community jobs will get done even though no individual does the whole job.

The four commitments described here are not unique to scientific discourse, but many worthwhile kinds of discourse do not involve all four commitments. Debaters do not aim at mutual understanding but at defeating the opponent. Advertisers and political campaigners rely heavily on statements that are not vulnerable to empirical evidence. Trial lawyers do not adopt the commitment to expand the basis for discussion but, instead, try to refute every point that they can in the opponent's case. In contrast, a group of people discussing a play or an art exhibit might display all four of the discourse commitments, even though there was nothing scientific about the conversation. It might not be scientific, but one would expect it to be progressive. It would differ from ordinary small talk or exchange of opinions in that the conversation would get somewhere and would leave the participants feeling that they had gained in understanding as a result of participating in it. That is the kind of discourse that, applied to explanations of natural phenomena, results in scientific progress.

\section{Progressive Discourse in Elementary School}

From the preceding discussion, it follows that, if students can carry on progressive discourse aimed at explaining natural phenomena, then they are doing science--regardless of their knowledge or their mastery of research procedures. But can young students be expected to honor the discourse commitments outlined here and carry on discussions that actually advance their collective knowledge beyond that of any individual student? To approach that question, one needs some idea of what progressive discourse might be like at an elementary school level.

As an example, we describe one discussion that went on over a period of almost 3 months among 17 sixth-grade students in the Taft Middle School, a public middle school in Cedar Rapids, lowa. The discussion was carried on by means of notes entered into CSILE, a networked computer environment 
designed to support knowledge-building discourse (Scardamalia \& Bereiter, 1994; Scardamalia, Bereiter, \& Lamon, 1994). The format used in this case was the discussion note (Scardamalia, Bereiter, Hewitt, \& Webb, 1996), which is an extended note with entries by different students appearing one after the other in chronological order. Individual entries are labeled according to "thinking type": P (Problem), MT (My Theory), INTU (I Need to Understand), NI (New Information), C (Comment), and WWHL (What We Have Learned). Any entry labeled INTU may be used as the beginning of a subdiscussion. The work we discuss was actually a subdiscussion initiated by a student, branching off from a discussion that had been initiated by one of the student's four teachers. The subdiscussion was titled "About Growing" and comprised 179 entries.

Initially, the discussion consisted mainly of students expressing their personal interests and concerns with growing. The adolescent growth spurt was the dominant topic, with some students concerned about when it would start for them and others concerned about when it would end. "Well, as you know, I'm one of the shortest people on this team," says one student. "I hardly grow any over a year's time.... It actually feels like I'm shrinking. Everyone else is growing...."' "I know that I am going to be a tall person, but in a way I don't want to be a tall person," says another. There is a pervasive sense of being under the control of forces they do not understand and can do nothing about. At the same time, several of them wonder what it must be like to be done growing, and they ask their teacher whether it feels weird to be the same size year after year.

So far, it is a worthwhile discussion, and the students are amazingly supportive of one another, but it is not a discussion that anyone would call scientific. A desire to move beyond expression toward understanding emerges quickly, however, and it takes the form of scientific conjectures. One student wonders if growth rate is hereditary, another wonders whether trees have growth spurts; one suggests that "people stop growing when the clock inside their head says they should," another that growing stops when the body runs out of material with which to grow.

The students are not merely expressing opinions for the sake of being heard. There is a clear expectation of working together to figure things out. Entry number 33 reads:

Everyone: If you have a theory on mine and Jake s INTU [I Need to Understand], please write it, and maybe we can combine them and have more new learnings.

Thus, the students are honoring the first commitment, to seek mutual advances in understanding. Having formulated questions and conjectures, the students begin drawing on a wide range of library resources, and much of the ensuing discussion relates to the third discourse commitment: expanding the basis for discussion. The basis, in fact, expands dramatically. Whereas, initially, growth was discussed only in terms of reaching adult height, new 
information brought into the discussion greatly extends the range of issues related to understanding growth. For example:

$¥$ Hair and nails keep growing after growth in height stops. So in some respects we never stop growing.

$¥$ We also keep growing in knowledge, but it is said that babies are born with all the brain cells they will ever have. So what kind of growth is this?

$¥$ Elderly people are said to get smaller. Is this a reversal of growing or something else?

$¥$ Growth is not uniform. The wrists grow more than the rest of the arm.

$¥$ Skin cells on humans and leaves on trees die and are replaced. Is this growth?

$¥$ Trees and other plants also appear to grow rapidly when they are young and then to slow down or stop growing. Is this the same process as in animals?

Throughout the discussion, there is a concern with the second commitment, empirical testability: how do experts know such-and-such? How could we find out? One student raises an explicit question of this kind: "I wonder how doctors or other people that have knowledge about growing know how tall you might be and what age you might stop growing. The doctor has predicted l'll be 5'4". He also thinks that my sister is finished growing, and he used to think that she was going to be very tall. Do they look for patterns?"

Heredity is an issue that comes up repeatedly. Will one end up being the same size as one's parents? One student reported having read that height of parents is not a major factor. The students decide to conduct a survey. A questionnaire is constructed, asking for students' and parents' heights. Grandparents are included as well, to check on the question of shrinkage in oldage. Although the students voice concerns about the validity of the data (some of the reported heights are suspect), they conclude tentatively that there is not much relationship between the heights of students and their parents. Actually, with some students into their adolescent growth spurt and others not, there is too much random variability for any strong relationship to appear. (Height at ages 12-13 is not highly correlated with one's own adult height, let alone that of relatives.) Although, understandably, the students do not recognize this problem with their research, they do figure out how to look for a relationship-by seeing whether students who report above-average height for their age report above-average heights of their parents.

The fourth commitment, openness, seems to be honored in this discussion, but not in the most obvious way. No deeply held beliefs are called into question, probably because no deeply held beliefs are standing in the way of the inquiry. But considerable openness is shown to deviant ideas, which is part of the same commitment. One student suggested that it might be possible to crossbreed plants and animals and thus produce an animal that could manufacture its own food, through photosynthesis. This suggestion was not only off the track of the discussion, which involved plants only to the extent of 
considering whether growth followed rules similar to those for animals, but the student who offered it was not even part of the team carrying on the discussion. He was someone in another group who had read the discussion note, had become interested, and had started to contribute (this is something that can be allowed or restricted in CSILE, as teachers or note authors wish). The response, however, was wholly supportive and constructive:

Ryan, I think you have come up with an interesting theory. I think you should do a little research on that, and if you need any help just ask me....

Ryan, That is a very interesting theory. But, I believe that that might throw our entire ecological balance out of whack... .. [Several cogent objections follow.] I am not attacking your theory, but I do not believe that it would work. There seem to be many loopholes that you did not anticipate.

Enough interest is generated, in fact, that a subdiscussion on photosynthesis in animals is started, thus allowing the main discussion of growth to stay on track.

The last entries in the discussion consist of students' reflections on what they have learned. These entries are under the WWHL (What We Have Learned) label, a standard part of the discussion note format that was used. The following are excerpts from one student's reflective summary:

We have worked incredibly hard on this note. It has been growing and growing.... Discussion and learning has changed greatly over the few months. We have had great ideas, some of which have been rather strange.... But, even though these were strange, they were interesting, and well thought about.

At the start of this note, we talked about what it was like to stop growing. And, me being vertically challenged, as I prefer to be called, was asked a lot of questions. I was asked about my brother's height, how much I grew a year, and things like that. We thought about what it would be like to stop growing.

Many adults wrote in, and students asked their parents what they thought. But, as most learning goes, we weren't happy. We wanted to know "why" we stopped growing. This led to many people studying things such as the pituitary glands, and hormones, and learned about all that stuff that we consider rather gross. But we learned a lot, which helped us understand why we stopped growing.

Students remark on the many facts and ideas they have acquired, but an underlying theme is that of conceptual change, a significant deepening and expanding of their conception of what growth means: "Many of my theories have 
changed since I began working on this note. ... I thought that you stopped growing. But, as my research continued, I learned that you never stop growing. Your hair, nails, and mind is always growing and expanding. You grow in maturity and of course you grow in weight. I thought that tendons just stretched and I didn't know much about bones and what they are made of."

The students also seem somewhat awestruck by what they have accomplished, and they are eager to repeat or continue the experience. One student remarks, "It is amazing to think that such a complex discussion note evolved from a single INTU (I Need to Understand) about how people feel at different heights." Another says, "I feel that we did a good job making theories but that we needed more time to get new learnings. I would still like to continue my research on this and write in next year with more new learnings. I think that we should learn stuff . . . over the summer and share it with the others in the fall. We can continue to write letters and make phone calls to experts though. I think that this research has been fun and we should pick it up next year or start a new one about the brain and its growth." Another concludes, "I hope we can all get together next year and try to get more people involved."

\section{Knowledge-Building Discourse as an Educational Objective}

We do not want to suggest that inquiries like the one just described are easily achieved in elementary schools or anywhere else, for that matter. Although the teacher's presence was not conspicuous in the discussion note itself, a great deal of thought and effort on the part of four teachers, working as a team, went into creating a school environment oriented toward collaborative knowledge building and into modeling the processes and attitudes that make it work. Both a teacher and a CSILE researcher entered comments into the "About Growth" discussion. Although these were few in number and in no way dominant, they probably contributed significantly to shifting the discussion toward problems of explanation. The CSILE technology was probably also important in sustaining focused inquiry over a period of months. But this discussion was by no means unique. We have seen comparable ones at other schools and on less engrossing topics (Scardamalia \& Bereiter, 1994).

CSILE is structured as a communal database running on networked computers. Unlike electronic mail, communication is not person-to-person but takes the form of notes entered into the database and retrievable by keywords, author, topic, and so on. Students' note entries are all publicly available for commenting and linking to other notes. Discussion notes are multiply authored notes that the authors can keep adding to over a period of time, but a discussion note can be retrieved by nonauthors and--if authorship is open they can become contributors to the note, as occurred in Ryan's case.

Unfortunately, it is beyond our scope in this article to address the large question of how to bring knowledge-building discourse of this kind about and what the limitations might be on its attainability in different student populations, curriculum structures, and so on. Prior to any such practical considerations, however, the issue of what one is striving for must be addressed. We have 
tried to show a kind of classroom discourse that does more than demonstrate a range of thinking skills and knowledge. It is, literally, discourse that builds knowledge. It seems to us that enabling students to carry on such discourse should be treated as an integral part of science education and made explicit in curriculum guidelines. For if our preceding analysis of the role of progressive discourse in science is valid, then this kind of discourse must be regarded as more than merely a vehicle for teaching science content and methods. In a real sense, we have argued, knowledge-building discourse is scientific method, and so students who fail to master it have failed to master science.

Accordingly, we call attention to the following characteristics of the kind of discourse exhibited here that distinguish it from other kinds frequently promoted in schools:

1. Although empirical research is involved, the focus is not on the doing but on the understanding. (Note that the survey the students conducted was not planned in advance as part of the unit but came about as a way of answering questions that arose during the discussion.)

2. The focus is not on controversy but on collaboration. Students are not encouraged to take positions and debate them but to look for and develop bases for shared understanding.

3. Unlike typical school "projects," no tangible product is the goal of collaborative effort. Educators frequently assert that some form of report, exhibit, or presentation is necessary to motivate and give direction to students' long-term efforts (Brown \& Campione, 1996). But in this case the written trace of the discussion was all there was. Gains in knowledge and understanding were the only product, yet, after 3 months, students were urging that the work be continued the next year!

4. Although what the students were doing has all the marks of scientific inquiry, it was not launched as a science unit, and the word "science" hardly ever appears. It was launched as a sharing of personal concerns and it evolved gradually into a wide-ranging scientific inquiry. This suggests that, for these students, knowledge-building discourse was a well-enoughlearned social practice that they could slide into it naturally, without explicit direction, when it became appropriate to their goals. That, at any rate, is the end point educators should hope for students to reach, so that the practice of knowledge-building discourse becomes something they can carry with them into other situations.

\section{Feeling at Home in a Knowledge-Based Society}

A common view of science, unfortunately encouraged by postmodernists, is of a highly specialized activity carried out by an elite group of rather strange and dangerous people. We believe the kind of discussion described in this article can serve as a paradigm for a different view of science and science learning, one better suited to the world students are growing up into.

A term frequently applied to the world students are growing into is "knowledge-based." This term implies not only that workers in the future will 
need a great deal of knowledge but that they also must be able to work with knowledge-creating it, evaluating it, organizing it, finding new uses for it, and so on. Thus, disciplined work with knowledge is no longer the province of specialized and elite scientists and scholars but is becoming part of the practice in all kinds of industries and organizations (Drucker, 1994). The educational implications of this shift toward a knowledge-based society are only beginning to be worked out, but one implication seems fairly clear. Science, which used to be separated from other human concerns, with its own subject matters and methods, is now becoming an integral part of people's daily lives. Increasingly, to be alienated from science is to be alienated from society.

This is not at all to say that science represents the only means of understanding and belonging. When one student writes to his "vertically challenged" classmate, "You probably just haven't hit your growth spurt yet. Maybe one day you'll wake up and be taller than everyone else," this is not science talking, it is compassion. But five entries later this same student is proposing a potentially testable theory about why bones stop growing whereas fingernails do not. The world for these students is not partitioned between scientific issues and non-scientific ones. The students move freely in and out of modes of thought, depending on the situation and their purposes. Neither is their world partitioned between scientists and experts on one side and themselves on the other. They value experts for what they can contribute, but at the same time they freely question the bases of the experts' knowledge and recognize the experts as human beings subject to the same shortcomings as themselves.

In another CSILE-based class in the same school, students concluded that a visiting expert on the Arctic tundra had a faulty explanation for why trees do not grow there. However, they took the trouble to try to determine the expert's likely reasons for believing as he did.

This seems to us a healthy kind of attitude and practice to bring into the knowledge age. Postmodernists want to cut scientists down to size. In this article we have tried to convey an idea of what it could mean to bring students up to size, instead.

\section{Notes}

We wish to acknowledge the support of the James S. McDonnell Foundation, through its Schools for Thought initiative, and the Taft Middle School: Alinda Hakinson, principal; Myrna Cooney, Bill Peters, and Karen Wesack, members (along with the third author) of the teaching team; and the students themselves who produced the knowledge-building discourse examined in this article. 
1. In all the quotations from the student da-tabase, punctuation and spelling $h ¥ v$ e been cor-rected and real names have been replaced withpseudonyms. OtheMTise, the quotations are ver-ba¥m.

\section{References}

Bereiter, C. (1994). Implications of postmodemism for science, or, science as progressive discourse. Educational Psychologist, 29(1), 3-12.

Bleier, R. (Ed.). (1988). Feminist approaches to science. New York: Pergamon.

Brown, A. L., \& Campione, J. C. (1996). Psychological theory and the design of innovative learning environments: On procedures, principles, and systems. In L. Schauble \& R. Glaser (Eds.), Innovations in learning: New, environments for education (pp. 289-325). Nahwah, NJ: Erlbaum.

Drucker, P. F. (1994, November). The age of social transformation. Atlantic Monthly, pp.53-80.

Dunbar, K. (1993). How scientists really reason: Scientific reasoning in real-world laboratories. In R. J. Stemberg \& J. Davidson (Eds.), The nature of insight (pp. 365-395). Cam-bridge, MA: MIT Press.

Gill, D., \& Levidow, L. (Ed.). (1987). Anti-racist science teaching. London: Free Association Press.

Grice, H. P. (1975). Logic and conversation. In P.Cole \& J. J. Morgan (Eds.), Syntax and semantics: Vol. 3. Speech acts (pp. 41-58). New York: Academic Press.

Harman, G. (1986). Change in view: Principles of reasoning. Cambridge, MA: MIT Press.

Kelley, G. J., Carlsen, W. S., \& Cunningham,C. M. (1993). Science education in sociocultural context: Perspectives from the sociology of science. Science Education, 17, 207-220.

Kuhn, T. (1970). The structure of scientific revolutions. Chicago: University of Chicago Press.

Kyle, W. C., Jr. (1991). The reform agenda and science education: Hegemonic control vs.counter hegemony. Science Education, 75, 403-411.

Lakatos, I. (1970). The methodology of scientific research programmes. In I. Lakatos \& A. Musgrave (Eds.), Criticism and the growth of knowledge (pp. 91-195). New York: Cambridge University Press.

Lash, S. (1990). Sociology of postmodernism. London: Routledge.

Lemke, J. (1990). Talking science: Language, learning and values. Norwood, NJ: Ablex.

Miller, M. (1987). Argumentation and cognition. In M. Hickman (Ed.), Social and functional approaches to language and thought (pp. 225-249). New York: Academic Press.

Popper, K. (1962). Conjectures and refutations: Thegrowth of scientific knowledge. New York: Basic.

Rorty, R. (1991). Objectivity, relativism, and truth: Philosophical papers (Vol. 1). Cambridge: Cambridge University Press. 
Scardamalia, M., \& Bereiter, C. (1994). Computer support for knowledgebuilding communities. Journal of the Learning Sciences, 3, 265-283.

Scardamalia, M., Bereiter, C., Hewitt, J., \& Webb, J. (1996). Constructive learning from texts in biology. In K. M. Fischer \& M. Kirby (Eds.), Relations and biology learning: The acquisition and use of knowledge structures in biology (pp.4P64). Berlin: Springer-Verlag.

Scardamalia, M., Bereiter, C., \& Lamon, M. (1994). CSILE: Trying to bring students into world 3. In K. McGilley (Ed.), Classroom lessons: Integrating cognitive theory and classroom practice (pp. 201-228). Cambridge, MA: MIT Press.

Smith-Allen, M. (1992). A post modern inquiry into the language of art criticism. Inquiry: Thinking Across the Disciplines, 9(3), 3-6.

Stanfield, J. H. (1985). The ethnocentric basis of social science knowledge production. Review of Research in Education, 12, 387-415.

Thagard, P. (1989). Explanatory coherence. Behavioral and Brain Sciences, 12, 435-502.

Whitson, J. (1991). Post-structuralist pedagogy as counter-hegemonic praxis (Can we find the baby in the bathwater?). Education and Society, 9(1), 73-86. 